\title{
COLONIALIDADE DA MEMÓRIA: apagamentos da luta pela terra Guarani e Kaiowá na constituição do moderno agronegócio brasileiro
}

\author{
Luciana de Oliveira $^{1}$ \\ Pedro Bomba ${ }^{2}$
}

\begin{abstract}
Resumo: No artigo buscamos delinear o dispositivo de colonialidade da memória obviando a relação entre genocídio indígena e a campanha publicitária "Agro: indústria-riqueza do Brasil", a partir do caso do povo Kaiowá (MS/Brasil). Buscamos caracterizar tal arranjo discursivo a partir do gesto metodológico que soma análise de conteúdo e pesquisa etno-histórica a partir de: 1) dados históricos de violação de direitos dos Guarani e Kaiowá no Relatório Figueiredo e dados atuais produzidos acerca de mortes violentas bem como seus enquadramentos e reverberações midiáticas; 2) a propaganda do chamado "novo rural brasileiro" e recordes produtivos do agronegócio. $\mathrm{O}$ objetivo é mostrar que tal dispositivo não é parte de um passado distante mas que reatualiza memórias nas mídias como forma contemporânea da colonialidade do poder.
\end{abstract}

Palavras-chave: Colonialidade da Memória; Dispositivos midiáticos; Genocídio indígena; Guarani e Kaiowá.

Abstract: In the article we seek to outline the coloniality of the memory dispositive that puts in relation indigenous genocide and the advertising campaign "Agro: industry-wealth from Brazil", from the case of the indigenous people Kaiowá (MS/Brazil). We seek to characterize such a discursive arrangement based on the methodological gesture that adds content analysis and ethno-historical research based on: 1) historical data on the violation of Guarani and Kaiowá rights in the Figueiredo Report and current data on violent deaths as well as their framing and media reverberations; 2) the propaganda of the "new Brazilian countryside" and agribusiness productive records. The aim is to show that such a dispositive is not part of the distant past but is re-embodied in the media's memories as a contemporary form of the coloniality of power.

Keywords: Coloniality of memory; Midiatic dispositives; Indigenous genocide; Invisibility; Guarani and Kaiowá indigenous peoples.

\section{Introdução}

O mundo rural brasileiro é, na contramão de certa propaganda festiva do agronegócio e do Estado brasileiro, em especial a campanha publicitária "Agro indústria-riqueza do Brasil" (2016-2018) ${ }^{3}$, constituído por uma história invisibilizada de genocídio e violenta expropriação de terras, saberes e trabalho indígenas, algo que foi minuciosamente descrito, a partir de fontes orais e escritas, num documento elaborado e, acreditava-se, queimado, no período da

\footnotetext{
${ }^{1}$ Docente do Departamento de Comunicação Social e Programa de Pós-Graduação em Comunicação Social da UFMG. Pós-doutoranda no INCTI/UNB (2018-2019), coordenadora do projeto de pesquisa "Regimes de Conhecimento e Formas de Vida na Universidade: experiências e experimentos cosmopolíticos em face de conhecimentos tradicionais e outras epistemologias do (in)visível (com financiamento do Edital Universal da Fapemig/2017) e do Programa de Extensão Imagem Canto Palavra no Território Guarani e Kaiowá em interface com a pesquisa "Te'e: Descendentes" (com financiamento do Edital Rumos do Itaú Cultural/2018).

${ }^{2}$ Mestrando do Programa de Pós-Graduação em Comunicação Social (PPGCOM/UFMG). É autor dos livros "O chão dispõe a queda", (2017 - Lab. Cucuruto da Cabeça) e "Extremamente barulhentos certos assuntos, por exemplo" (2018 - Editora Urutau).

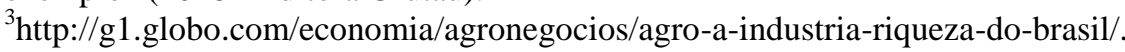


Ditadura Militar (1964-1985) no Brasil, o chamado Relatório Figueiredo ${ }^{4}$. Sua reaparição em 2013 ganhou certa visibilidade e as reverberações institucionais e midiáticas do achado, por ocasião dos trabalhos da Comissão Nacional da Verdade (2011-2014), colocaram em relevo os problemas da violência contra os povos indígenas no país. Já a campanha publicitária anteriormente citada é uma iniciativa da Rede Globo de Televisão que, nas palavras do diretor de marketing da emissora, Roberto Schmidt, expressa o desejo de "mostrar que a riqueza gerada pelo agronegócio movimenta os outros setores da economia" e "fazer com que o brasileiro tenha orgulho do agro"

Mato Grosso do Sul é o estado brasileiro onde se assiste a um dos conflitos fundiários mais graves do país. É o estado que mais tem acumulado recordes produtivos no campo ${ }^{6}$ e que reúne a segunda maior população indígena do Brasil ${ }^{7}$. O alto rendimento da produção agrícola e o grande poder econômico e político dos produtores é um dos fatores que tem atrasado as demarcações de terras no estado, em geral justificados por pensamentos integracionistas e assimilacionistas, pela negação da identidade étnica e dos direitos originários à terra - tal como assegura a Constituição Brasileira de 1988. Também é disparadamente o estado em que mais indígenas morrem por causas violentas, incluindo assassinatos. No entanto, pouco ou nada se fala quanto à presença indígena nessas fronteiras agrícolas e sobre os dados alarmantes de violências contra essa população. Tampouco se fala sobre os danos ambientais das extensas áreas que eram cobertas por espessa vegetação de cerrado e mata atlântica (daí o nome do Estado) alternadas com campos cultiváveis nos quais os povos Guarani e Kaiowá desenvolveram técnicas e conhecimentos de manejo e cultivo de variadas espécies, além de pesquisas zoobotânicas, hidrográficas, topográficas, geológicas, medicinais e outras.

\footnotetext{
${ }^{4}$ Conjunto documental de 30 volumes (dos quais reapareceram 29) que reúne mais de sete mil páginas, encontrado por Marcelo Zelic da organização não-governamental Tortura Nunca Mais!, no Museu do Índio em abril de 2013, testemunho dos crimes cometidos pelo Estado brasileiro contra comunidades indígenas em todo o país, ao longo da ditadura militar. O Relatório Figueiredo foi incluído nas investigações da Comissão Nacional da Verdade (CNV) e nas conclusões de seu relatório final (texto 5, vol. 2, "Violações de direitos humanos dos povos indígenas" disponível em http://www.cnv.gov.br/).

${ }^{5}$ Em matéria publicada pelo site StartAgro. Disponível em: http://www.startagro.agr.br/por-que-o-agronegocioprecisa-de-uma-comunicacao-moderna/ Acesso em 09/05/2018. Na mesma matéria as palavras de Schmidt são endossadas pelo ex-ministro da agricultura Roberto Rodrigues e pelo presidente da Embrapa Maurício Lopes.

${ }^{6}$ Os recordes são sucessivos, a cada ano, e ligados às diversas commodities agrícolas comercializadas pelo estado: soja, milho, cana-de-açúcar. Ver, por exemplo, http://www.portalsyngenta.com.br/noticias-docampo/ibge-estima-safra-recorde-de-graos-no-mato-grosso-do-sul\#.

${ }^{7} \mathrm{O}$ Amazonas é o primeiro, com 183.514. Em MS, são 77.025 pessoas. O maior grupo indígena são os Kaiowá e Guarani - 43,4 mil pessoas, segundo o IBGE de 2010, vivendo em 30 terras indígenas e mais de 30 acampamentos provisórios que não chegam a representar 42 mil hectares de terra, na região sul do estado, justamente onde se concentram, há décadas, as grandes lavouras de soja e cana, além de expressiva pecuária. Ao todo, o Censo de 2010 do IBGE encontrou 896.917 indígenas. Dados compilados por Pimentel (2012).
} 
Nossa perspectiva, nutrida pela abordagem decolonial latino-americana (QUIJANO, 1992; 2005; DUSSEL, 1992; 2005; MIGNOLO, 2000; 2015; WALSH, 2002; GROSFOGUEL, 2008; BALLESTRIN, 2013), tendo como referência o caso de MS, implica dizer que a modernização do mundo rural implica sua contra-face, a colonialidade do poder, do saber, do ser e, como aqui sugerimos, da memória, que se constitui nas práticas cotidianas de racismo/preconceito étnico como também nas blindagens institucionais de equidade na distribuição da terra, combinação que caracteriza os processos contemporâneos de comoditização da terra que Raquel Rolnik (2015) chamou de "insegurança jurídica da posse da terra". Assim, pretendemos discutir que um dos modos de exclusão, invisibilização e subalternização da experiência indígena é aquele que exalta a modernidade e oculta a colonialidade e, no que se refere à memória, às incidências do colonialismo sobre as disputas do lembrar/esquecer e sobre as construções narrativas da história que têm ocorrido em terreno midiático, embora não só.

Para tanto, valemo-nos, metodologicamente, do exame Relatório Figueiredo em busca dos relatos/documentos que, em seu interior, denunciam situações graves de violações de direitos das pessoas indígenas Kaiowá e Guarani bem como de um conjunto de matérias publicadas por ocasião da sua "descoberta". O percurso metodológico que sustenta o artigo inclui ainda uma etnografia multissituada (OLIVEIRA, 2017) nos territórios indígenas, especialmente em terras retomadas (tekoha) e da pesquisa na literatura histórica e antropológica que apoiaram/apoiam essa incursão. Com esse amparo, aqui o que se buscou foi um modo de sistematizar materialidades midiáticas produzidas por veículos de comunicação bem como nos documentos históricos e dados quantitativos de pesquisa a fim de cotejá-los, sem deixar de considerar que são dispositivos de visibilidade arquitetados dentro de seus contextos específicos, mas que se ligam ao complexo relacional da colonização/ luta pela terra historicamente construído. A ênfase analítica, portanto, não se dá por comparação dos materiais mas pela criação de um nexo entre eles. Para selecionar o corpus de análise, delineamos os seguintes procedimentos de recorte:

a) Documentos históricos coletados do Relatório Figueiredo: realizamos uma busca sistemática no documento a partir de distintas palavras e expressões-chave para uma varredura das incidências envolvendo os povos Kaiowá e Guarani do MS ${ }^{8}$. Dos 52 registros

\footnotetext{
${ }^{8}$ As palavras e expressões-chave utilizadas na varredura, considerando as diversas grafias de Kaiowá e os grupos indígenas do qual se original ou com os quais guardam relações, foram: Kaiowá, Kaiova, Kaiová, Kaiwoá, Caiua, Caiuvá, Caiová, Caiuva, Caiova, Guarani, Ñhandeva, Ñandeva, Nhãdeva, Mbya, Mbia, Imbia, Cayua,
} 
encontrados que dizem das várias formas de violações de direitos constituídas historicamente na região e documentadas no Relatório Figueiredo, foram utilizados aqui 14, um exemplo de cada tipo de violação de direitos humanos. Ademais, trabalhamos com o Relatório "As violações contra os povos indígenas em Mato Grosso do Sul e as resistências do Bem Viver por uma terra sem males 2003 -2010", , produzido pelo Centro Indigenista Missionário (CIMI) e publicado em 2011 como forma de demonstrar a continuidade das violações de direitos humanos e dos assassinatos no presente.

b) Materialidades midiáticas: utilizamos matérias e reportagens publicadas no site de notícias G1 e no site de notícias Universo Agro $^{10}$ referentes à produção de soja no Mato Grosso do Sul. Cabe destaque à reportagem "Produção supera expectativas e MS colhe supersafra com 8,497 milhões de toneladas de soja”, de 20 de abril de 2017, e a matéria “Agronegócio é valorizado em campanha da Rede Globo”, de 01 de outubro de 2016, publicadas no site de notícias G1, respectivamente, além do editorial "Agronegócio tem que mostrar à sociedade a tecnologia utilizada no campo”, publicada no Uagro, de 31 de março de 2017. Também analisamos os vídeos da campanha "Agro é pop, agro é tech, agro é tudo" disponíveis no Youtube.

\section{Colonialidade da memória}

Em quais circunstâncias se realizam as grandes produções agrícolas no Mato Grosso do Sul? Será que a situação histórica de assassinatos, confinamentos, abusos e exploração vividas pelos Guarani e Kaiowá não é também de interesse da população brasileira e da opinião pública internacional, assim como as superações de safras? É possível afirmar semelhanças entre as violações cometidas durante a ditadura militar e as violações cometidas

Pai-Tavyterã, Tembekuára, Ache, Guaicurus, Aldeia Taguapery (Serro Peron) - município de Amambaí, Posto Indígena Benjamin Constant - município de Amambaí, Posto Indígena Francisco Dourado - município de Dourados, Aldeia Ramada (Sassoró) - município de Amambaí, Aldeia Pirajuí - município de Amambaí, Posto Indígena José Bonifácio - município de Dourados. Agradeço às bolsistas de IC (Jovens Talentos CAPES) Flávia Ruas e Natália Amaro que realizaram a coleta de dados.

${ }^{9}$ Relatório "As violações contra os povos indígenas em Mato Grosso do Sul e as resistências do Bem Viver por uma terra sem males 2003 -2010" (http://www.cimi.org.br/pub/MS/Viol_MS_2003_2010). A partir desse trabalho foi também desenvolvida a Cartografia de Ataques Contra Indígenas (CACI) com apoio da Fundação Rosa de Luxemburgo, uma interessante iniciativa de jornalismo de dados, na qual foram disponibilizados todos os casos de violência contra indígenas no Brasil e instrumentos de pesquisa com diversos tipos de filtros, no período de 1984-2016 (http://caci.cimi.org.br/\#!//?loc=-13.068776734357694,-63.80859374999999,4)

${ }^{10}$ Site Universo Agro http://www.uagro.com.br/. 
nos últimos dez anos? Ou talvez, hipoteticamente, levantar as continuidades de um processo de apagamento, invisibilização e extermínio em longa duração histórica?

Essas perguntas, inicialmente levantadas no contato com nossa empiria, nos levaram a uma aliança reflexiva com o pensamento desenvolvido por intelectuais do grupo Modernidade/Colonialidade que têm tentado demonstrar como as trajetórias históricas dos países da América Latina foram constituídas a partir de paradoxos que sustentam o moderno a partir da herança colonial ${ }^{11}$. Nessa trilha, a experiência social está assentada naquilo que Mignolo (2000) chamou de diferença colonial: a permanência de critérios classificatórios, em outros momentos da história da colonização como instituição legal e moralmente constituída considerados científicos e a-históricos, universais baseados em "raças", "etnias" e "nações" que permanecem na separação hierárquica entre Europa/EUA e países ao sul nas Américas, na Ásia e na África e, de modo mais consistente e concreto, em construções intersubjetivas que mantêm as linhas de força do poder colonial desde a conquista desses continentes até os dias atuais, ainda que o colonialismo como política institucionalizada tenha acabado. O genocídio das populações originárias, no caso da América Latina (AL), tem um papel central nas relações de modernidade/colonialidade pois significou além da violenta destruição de vidas, famílias e etnias inteiras em alguns casos, a destruição de altas produções culturais e científicas. A base das redes de poder global contemporâneas se valem ainda hoje da subalternização ocasionada por essa devastação de formas de vida e formas de conhecimento cuja herança atua contemporaneamente em nível político, subjetivo e epistemológico.

Pari passu com a violência e a exploração de riquezas na AL, havia todo um conjunto de formas de explicação da exploração e do genocídio criadas na "racionalidade" européia, uma geopolítica do conhecimento (MIGNOLO, 2000) que gestou e constituiu a universalidade da ciência moderna. O princípio da universalidade da filosofia moderna caminha de mãos dadas com os interesses do capitalismo. Para Mignolo (2000), "Quijano y

\footnotetext{
${ }^{11}$ Modernidade/colonialidade é um conceito usado por Aníbal Quijano (1992; 2005) e depois desenvolvido por Walter Mignolo (2000; 2015). Alinha-se com certos questionamentos colocados pelos estudos pós-coloniais indianos e africanos, buscando ênfase na relação entre colonialismo e as narrativas da modernidade, especialmente pensada como um quadro epistemológico que é inseparável do projeto colonial europeu. Catherine Walsh chama a esse labor intelectual e atitudinal de decolonialidade. Ballerstrin (2013) produziu uma excelente síntese do que é esse programa de investigação, cuja urdidura a autora chama de giro decolonial. Como assinala Mignolo (2008) a colonialidade do poder é essencialmente uma colonização do conhecimento, das imagens, dos símbolos, do pensamento. No plano econômico e político tem parentesco explicativo com a teoria da dependência, mas à diferença desta que não considera a diferença colonial como diferença epistêmica, defende a necessidade de uma disputa no campo mesmo da ciência, em vez de seguir o modelo eurocêntrico hegemônico.
} 
Dussel hicieron posible no sólo concebir un sistema mundial moderno/colonial como una estructura socio-histórica coincidente con la expansión del capitalismo sino, también, concebir la colonialidad y la diferencia colonial como loci de enunciación". Segundo Ansara (2012), interpretando o pensamento de Aníbal Quijano, essa enunciação coloca em primeiro plano os discursos da modernidade e da civilização ocidental, silenciando outras histórias frente a:

1) a "colonialidade do poder", isto é, a ideia de raça como fundamento do padrão universal de classificação básica e de dominação social;

2) o capitalismo, como padrão universal de exploração social;

3) o Estado como força central universal de controle da autoridade coletiva e o moderno Estado-Nação como sua variante hegemônica;

4) o eurocentrismo como força hegemônica de controle da subjetividade / intersubjetividade, em particular no modo de produzir conhecimento.

Assim, além da universalidade, outro ponto de sustentação da colonialidade, consequência do individualismo moral e científico, é a separação sujeito/objeto que aniquila as diferenças, tomando o Ocidente como referência da cultura e do conhecimento e objetificando todo o resto. Segundo Quijano (1992, p. 160):

la emergencia de la idea de "occidente" o de Europa, es una admisión de identidad, esto es, de relaciones con otras experiencias culturales, de diferencias con las otras culturas. Pero, para esa percepción "europea" u "occidental" en plena formación, esas diferencias fueron admitidas ante todo como desigualdades, en el sentido jerárquico. Y tales desigualdades son percibidas como de naturaleza: sólo la cultura europea es racional, puede contener "sujetos". Las demás, no son racionales. No pueden ser o cobijar "sujetos". En consecuencia, las otras culturas son diferentes en el sentido de ser desiguales, de hecho inferiores, por naturaleza. Solo pueden ser "objetos" de conocimiento y/o de prácticas de dominación. En esa perspectiva, la relación entre la cultura europea y las otras culturas, se estableció y desde entonces se mantiene, como una relación entre "sujeto" y "objeto".

É por isso que a colonialidade do poder opera também uma colonialidade do saber. O genocídio, enquanto extermínio de formas de vida e formas de conhecimento, é parte indissociável do mecanismo de criação da diferença colonial.

En América Latina, la represión cultural y la colonización del imaginario, fueron acompañadas de un masivo y gigantesco exterminio de los indigenas, principalmente por su uso como mano de obra desechable, además de la violencia de la conquista y de las enfermedades. La escala de ese exterminio (si se considera que entre el area azteca-maya-caribe y el área tawantinsuyana fueron exterminados alrededor de 35 millones de habitantes, en un periodo menor de 50 años fue tan 
vasta que implicó no solamente una gran catástrofe demográfica, sino la destrucción de la sociedad y de la cultura. Entre la represión cultural y el genocidio masivo, llevaron a que las previas altas culturas de América fueran convertidas en subculturas campesinas iletradas, condenadas a la oralidad. Esto es, despojadas de patrones propios de expresión formalizada y objetivada, intelectual y plástica o visual. En adelante, los sobrevivientes no tendrán otros modos de expresión intelectual o plástica formalizada y objetivada, sino a través de los patrones culturales de los dominantes, aun si subvirtiendolos en ciertos casos, para transmitir otras necesidades de expresión. (QUIJANO, 1992, p. 13).

Do ponto de vista subjetivo, a destruição e subalternização das altas culturas ante o olhar europeu ou ocidental e, no nível micropolítico das interações, para seus próprios operadores e criadores implicou a colonialidade do ser, outra dimensão da colonialidade. O mesmo movimento político e epistemológico ocorre com a separação natureza/cultura, tanto no que tange às escolhas produtivas quanto também à hierarquização das diversas formas de vida e estilos de invenção da cultura. As noções de progresso e desenvolvimento estão associadas a esse processo que toma o padrão europeu como espécie de cânone ideal e universal do bom viver.

Os mecanismos da modernidade/colonialidade operam na colonização dos imaginários e nesse ponto abrangem dimensões discursivas como a linguagem, a memória e o espaço (MIGNOLO, 2015), de onde se expandem ao conhecimento, à epistemologia como instrumento de colonialidade do saber. Ao estabelecer a diferença colonial como fundamento da dominação, o jogo político da memória consagra um só tipo de saber e um só tipo de vida (o europeu moderno) como digno de ser lembrado assim como subalterniza as outras memórias e formas de produção de historicidade que devem ser apagadas. Se a memória é coletiva, ou seja, não é resultado de voluntarismos individuais ou subjetivos, sua construção não se faz de forma consensual ou pacífica e está prenhe de mecanismos oficiais e cotidianos de opressão como também de criação de resistências. Assim, o processo envolve tanto "políticas de memória" quanto "políticas de esquecimento" (ANSARA, 2012), de acordo com Mignolo 2015:

El imaginario del mundo moderno/colonial surgió de la compleja articulación de fuerzas, de voces oídas o apagadas, de memorias compactas o fracturadas, de historias contadas desde un solo lado que suprimieron otras memorias y de historias que se contaron y la colonialidad a lo largo y lo ancho: el hemisferio occidental en el horizonte colonial cuentan desde la doble conciencia que genera la diferencia colonial. 
A colonialidade do poder atua a partir de mecanismos que se ativam e são constituídos numa vasta rede que engendra instituições, territórios, corpos, materialidades e temporalidades diferentes. Os media - considerando aqui tanto as linguagens quanto os artefatos técnicos e formas institucionais de distribuição de informação e entretenimento - são componentes essenciais de constituição das formações discursivas contemporâneas, especialmente se considerarmos processos de complexificação, globalização e midiatização. As disputas no terreno da história e da memória encontram solo fértil nos dispositivos midiáticos. A memória não é somente um movimento simples de lembrança do passado. Ela envolve um processo de construção coletiva no qual lembrar ou esquecer dependem de quais elementos detemos e o modo como eles são ativados nas interações. Além disso, todo exercício de história é um dever de memória que diz da leitura de um passado mas também de um futuro que queremos. Como lembra Gondar (2005, p. 17): "há sempre uma concepção de memória social implicada na escolha do que conservar e do que interrogar. Há nessa escolha uma aposta, um penhor, uma intencionalidade quanto ao porvir".

Para compreender os dispositivos de colonialidade da memória, no estudo do caso em tela, é preciso ainda destacar que, por um lado, há um desconhecimento arraigado sobre história indígena no Brasil que começa nas histórias das próprias famílias brasileiras e um etéreo passado indígena que as constitui e passa cotidianamente pelas chaves do índio genérico, do índio romântico, do índio do passado, do índio exótico, do índio selvagem e do índio que já não existe mais (FREIRE, 2000; MELATTI, 2007; CUNHA, 2009; 2012; GOMES, 2012; SOMMER, 2004; TACCA, 2011; BRAGA e CAMPOS, 2012). Menos ainda se sabe sobre a história de contato com os povos Guarani e Kaiowá em suas especificidades ${ }^{12}$. Por outro lado, há uma grande celebração dos ganhos econômicos da indústria agrícola e pecuária que alimentou, no campo da economia (SILVA, 1997; SILVA, 2001; ALENTEJANO, 2000; CAMPAGNOLA e SILVA, 2000; LAURENTI e DEL GROSSI, 2008), a emergência de um novo rural, integrado ao urbano (ou rurbano), a aparição de novas atividades no campo ligadas ao turismo, à moradia e à prestação de serviços, como também uma presença de "sem-sem" ou pobres rurais em crescimento. Em linhas gerais, essa

\footnotetext{
${ }^{12}$ Para combater tal desconhecimento foi criado no Brasil e/ou subscrito por ele um anteparo institucional legal que busca mitigar déficits no campo do ensino da história indígena, da formação de professores e cientistas indígenas, políticas de educação e respeito aos direitos indígenas. Exemplos disso é a Lei 11.645/2008 que alterou a Lei 9.394/1996, modificada pela Lei 10.639/2003, a qual estabelece as diretrizes e bases da educação nacional, para incluir no currículo oficial da rede de ensino a obrigatoriedade da temática "História e cultura afro-brasileira e indígena". Isso implica a necessidade de abordar a temática em questão no ensino de todas as disciplinas do currículo da educação básica, que inclui o ensino fundamental e médio.
} 
perspectiva defende que o novo rural é moderno, não representando mais o pólo do atraso na dicotomia cidade/campo.

Genocídio indígena: o que diz o Relatório Figueiredo sobre a violência contra os povos Guarani e Kaiowá

O Relatório Figueiredo é um extenso documento que foi produzido no período da ditadura militar no Brasil, a pedido do Ministério do Interior, ao qual estava ligado o Serviço de Proteção ao Índio (SPI), à época sob o comando do General Albuquerque de Lima . Ele ficou desaparecido por 45 anos sob a suposição de que teria sido eliminado num incêndio no Ministério da Agricultura. O texto final e a compilação dos documentos foram feitos pelo procurador federal, Jader de Figueiredo Correia, então coordenador da Comissão de Inquérito instaurada em 1967 para apurar irregularidades no SPI ${ }^{13}$. Após a varredura realizada na extensão total do documento com diversas chaves de entrada, foram encontrados 52 registros de ações/menções relativas aos povos Guarani e Kaiowá no MS e/ou de Reservas/Postos Indígenas nos quais foram confinados.

Tais menções são muito explícitas em relação às violações de direitos humanos ocorridas antes e durante o período militar, fundamentos tanto do tipo de visibilidade requerida por Guarani e Kaiowá que conhecem, "na pele", as histórias de que o documento é testemunho, quanto da visibilidade que argumentos hegemônicos têm nos veículos de mídia locais e nacionais que, na verdade, invisibilizam a história indígena. As violações são: esbulho de terras e roubo de gado e bens agrícolas dos indígenas, estupro de mulheres, comércio de pessoas, escravização, precariedade dos vínculos de trabalho e venda abusiva de álcool nos PI's. Os responsáveis por estas atrocidades são funcionários do SPI - agentes do Estado brasileiro -, políticos e latifundiários, operando de forma conjunta ou em separado.

O documento e os registros, depois de seu muito tempo de silêncio, dizem também do atual contexto de disputa por terras em MS que persistem sob a forma da colonialidade do poder e da memória. A fig.1 mostra parte do texto conclusivo do Relatório Figueiredo que, além de tratar das altas cifras arrecadadas com o arrendamento ilegal e venda de gado indígenas na $5^{\mathrm{a}}$ Inspetoria de Campo Grande, então estado do Mato Grosso, reduz os índios a sujeitos não esclarecidos e irresponsáveis.

\footnotetext{
${ }^{13}$ Dados disponíveis em: http://6ccr.pgr.mpf.mp.br/institucional/grupos-de-trabalho/gt crimes ditadura/relatoriofigueiredo, onde também se encontra o Relatório Figueiredo na íntegra.
} 
revista do programa de pós-graduação em comunicação social faculdade de comunicação e artes da PUC Minas

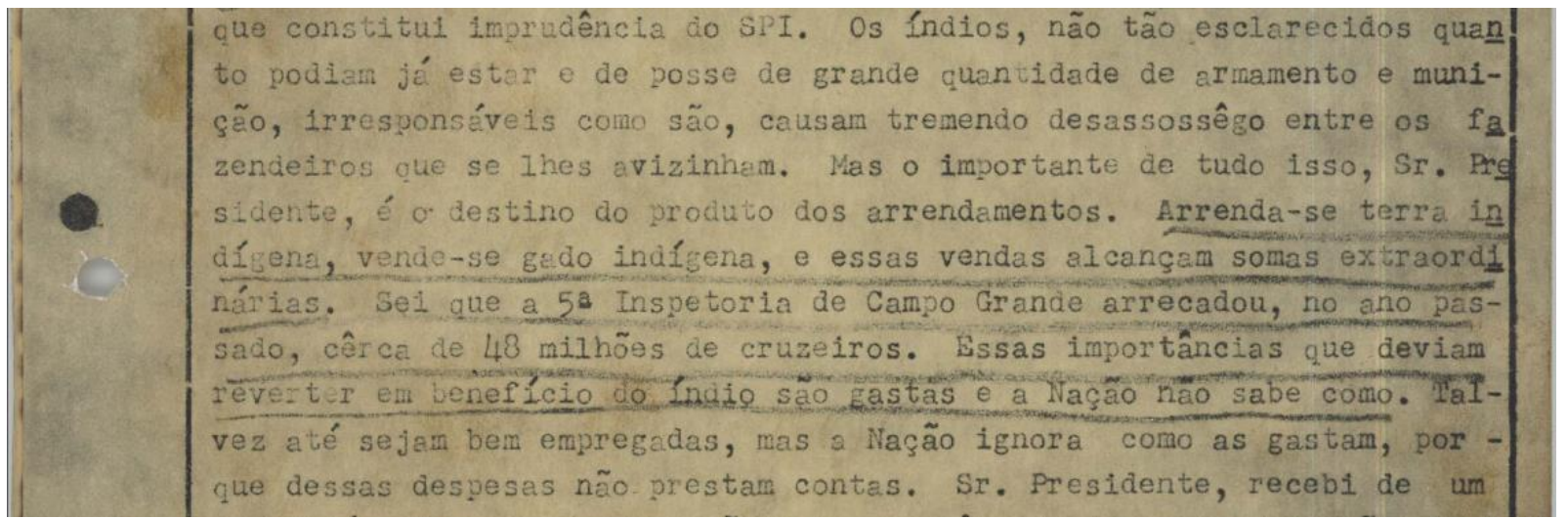

Fig. 1: sobre a venda de terras e bens indígenas.

Fonte: Relatório Figueiredo, p. 115. 
Já a fig.2, um documento interno do SPI, do ano de 1962, no qual o chefe da $5^{\text {a }}$ Inspetoria revela, com detalhes, denúncias de estupro de mulheres indígenas:

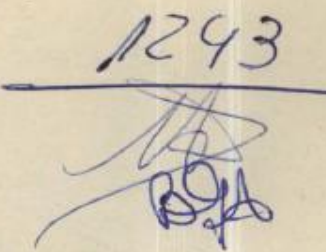

BOIETIM INTERNO DO SPI NO 57-MESES SET.-OUT.-NOV.-DEZ.-1962-49-

zados na região do Amambaí, encontrei gravíssimas irregularidades praticadas por funcionários desta Inspetoria. .

No P.I. José Bonifácio, tome1 conhecimento que $\circ \underline{A}$ gente IEONARDO CORREIA DA ROCHA, ex-Encarregado daquele Pôsto, estrupou quatro menores índias, bem como incendiou criminosamen te os hervals daquele Reserva:

Determinei ao Encarregado daquele P.I., Agente DILERMANDO SILVA as providências para a abertura de Inquérito Policial, pelo Delegado de Polícia da cidade de Dourados, a fim de responsabilizar criminalmente o praticante de tão grave deli to, que atenta contra a moral e costume tribal.

Solicito para êste caso as imediatas providências de V.Sa. mandando instaurur um Inquérito Administrativo, que pa ralelemente ao Inquérito Policial, caracterizará a responsab1l1 dade funcional naquela prática delituosa.

Quanto ao P.I. Benjamin Constant, deparei, também, com fatos de idêntica natureza. Determinei, também, que fôsse solicitada à autoridade Policial, da cidade de Amambá, a abertura de Inquérito Policial contra o Agente PANTAIEÃO BARBOSA DE OLIVEIRA, que é acusado de suborno para silenciar os reclamos de justiça do pai de uma menor índia por êle infelicitada.Pesa, ainda, sôbre êsse funcionário a acusação de deixar morrer à min gua, sem assistência médica e medicamentos o Capitão do Pôsto Benjamin Constant, por ter o mesmo contrariado êsse funcionário na prática dêsses atos de desrespeito à família indígena.

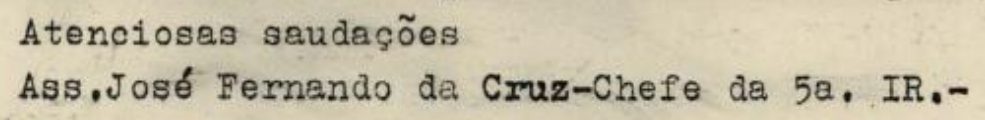

Figura 2: Sobre irregularidades na 5a Inspetoria e estupro de mulheres indígenas Kaiowá/guarani. Fonte: Relatório Figueiredo, p. 1243. 
$\mathrm{Na}$ fig.3, aparece um outro argumento recorrente na desqualificação das questões e lutas dos povos Kaiowá e Guarani que os coloca como índios não-brasileiros. Aqui, eles são ditos originários do Chaco boliviano, mas muitas vezes são ditos paraguaios. É preciso lembrar a força comunicativa dessa forma na medida em que ela tem raízes históricas no que refere às disputas de fronteira do Brasil e como a fronteira do Paraguai recuou após a guerra de 1870 (isso está inclusive na memória dos índios que, não raro, afirmam: "a fronteira do Paraguai vinha até o Rio Brilhante") quanto na vulgata de que coisas que vêm do Paraguai são falsas. Valdomiro Flores, xamã Kaiowá da tekoha Guaiviry, costuma, em suas reflexões, atestar que a Guerra entre a Tríplice Aliança e o Paraguai não acabou. Assistindo ao genocídio lento de seu povo, operado tanto pela matança da experiência social, das formas de organização e das relações multidimensionais com os antepassados, espíritos e paisagens quanto por extermínio violento, o pensamento do xamã se aproxima daquilo que a filósofa Judith Butler (2009) chamou de quadros de guerra, ou seja, quando efeitos de guerra se fazem sentir sem que a mesma seja declarada.

Tenho para mim, que êles sejam originários do CHACO BOLIVIA No, e tenham seu tronco racial nos MBAYAS; povo opulento que habitava na época das conquistas; uma margem e outra do Rio Para guał, entre os paralelos $20 \cong$ e $22 \%$, aproximadamente.

Devido às atrocidades cometidas contra êles nos meados do século XVII e princípio do XVIII século, pelos espanhois e paraguaios, imigraram para os lados de Mato Grosso, no Brasil, onde depois de conflitos com brasileiros, acomodaram-se com suas famí lies e foram bem acolhidos, identificados depois com o nome ge ral de GAUICURUS uns, e de CHANÉs, outros.

Pondo de lado, o estudo ou história dos GUAICURUS e seus sub-grupos, desejo me referir ligeiramente ao grupo CHANES, do qual se derivaram os TERENOS, os LAIANOS, os KINIKINAUS e os GUANAS, que falavam todos o mesmo dialeto com pequena ou nenhuma diferença.

Figura 3 - Sobre a ideia de que os indígenas não são brasileiros.

Fonte: Relatório Figueiredo, p. 283. 
Na fig.4, um depoimento de funcionário da $5^{\text {a }}$ Inspetoria, vemos atuar o mecanismo do esbulho de terra pelo Estado brasileiro, por meio do mecanismo de desapropriação, em prol do benefício privado de políticos (no caso, o então deputado federal pelo Arena, Rachide Mamed) e seus familiares.

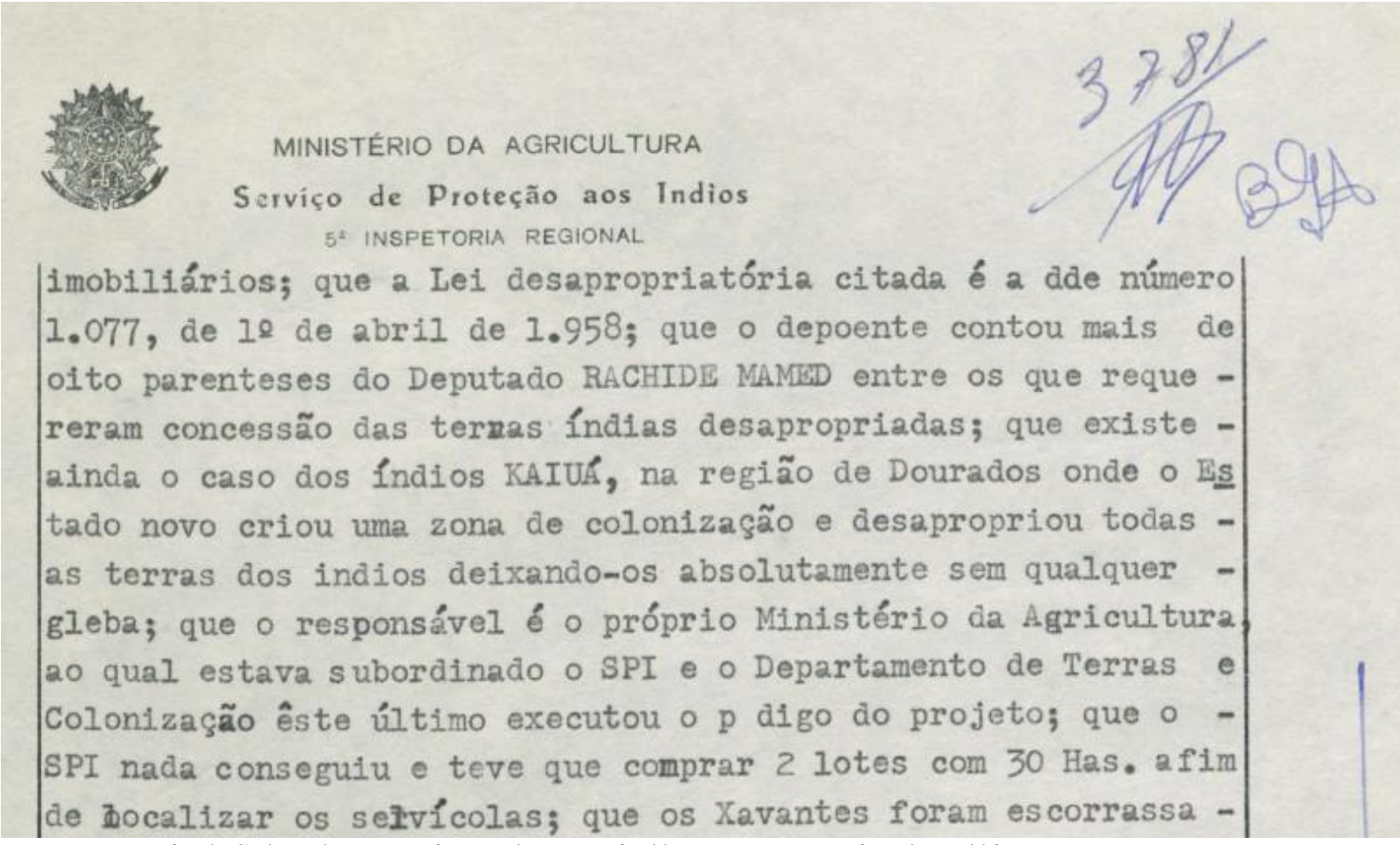

Fig.4: Sobre desapropriação de terras indígenas em proveito de políticos e seus parentes. Fonte: Relatório Figueiredo, p. 3781.

As relações de trabalho precárias, violentas e corruptas são objeto da fig.5, um documento da 5a Inspetoria Indígena que cria comissão de inquérito administrativo, a fim de apurar denúncias contra funcionários do SPI. É um testemunho interessante para confrontar um componente importante da colonialidade da memória no que tange à questão indígena no Brasil: um imaginário de que não existiu ou que, se existiu, foi algo residual, a escravidão indígena em nossa história ou de que o indígena não se adaptou ao trabalho escravo. Não raro, tal visão vem acompanhado de uma imaginação de que o índio é preguiçoso para o trabalho. Assim como os africanos trazidos forçadamente para serem escravizados ${ }^{14}$, os povos

\footnotetext{
${ }^{14}$ Negros da terra era o modo como os colonizadores chamavam o escravo indígena, distinguindo-o do escravo vindo de África. O trabalho historiográfico de John Manuel Monteiro (1994), documenta de forma minuciosa esse processo na formação do estado de São Paulo entre os séculos XVI e XVIII, mostrando como a economia do estado no que tange à mineração, criação de gado e expansão agrícola dependia, em larga medida, dessa mão
} 
indígenas também foram escravizados e o trabalho forçado não é uma realidade do passado, mas sim do presente como atestam investigações e números acerca de condições de trabalho análogas à escravidão no corte da cana, nas diversas lavouras, nos frigoríficos e nas usinas de álcool. No trabalho de campo, nos relatos sobre o trabalho forçado, os detalhes da ação ficam mais evidentes: os "cabeçantes", homens que trabalham para os proprietários de terra e/ou empresas de beneficiamento passam pelas reservas indígenas fazendo o recrutamento e de caminhão já transportam os trabalhadores sem nenhuma condição de segurança para os postos de trabalho. Em geral são períodos longos de trabalho, cerca de dois meses com intervalos que variam de 5 a 15 dias de folga para visitar a família. As jornadas de trabalho são longas e ininterruptas. As condições dos alojamentos são precárias e, muitas vezes, há "distribuição" de drogas e bebidas nos períodos noturnos e finais de semana. O pagamento é muitas vezes feito sob a forma de vale-compra e designa estabelecimentos comerciais específicos nas cidades próximas às reservas onde os produtos devem ser adquiridos. (GOMES, 2016). 
№ 23 , de 26 de fevereiro de 1962 .

o Diretor do Serviço de Proteção aos Indios,

RESOLVE designar, ex-vi do art. 219, da Lei número '

1.711, de 25.10.52, Ernani Luiz, Preparedor de Museu, EC-602-12^, co mo Presidente; João Domingos Lamônica, Laboratorista, nivel 9; e Jo ão Nozaré, Escrevente Datilógrefo, AF-204-7, do Quedro de Pesscal Parte Pormanonte dêste Ministóric, para comporem a Comissño de Inqué rito $\Lambda$ dministrativo instaurede pera verificar a exatidão das denun cias feitas contra DUC:STEL GUTMRRES, Motorista, CT-401-8, ex-Incarregado do Pôsto Indigona "José Bonifácio", da 5a. Inspetoria Regio nal, pelo Trabalhador Zacartas Marquos (índio), dovendo a Comissão de signada apurar:

a) sôbre possível violêncies praticedạs contre os ín dios, pelo acusado, quendo nas funções de Incarregado do Pôsto Indígena "José Bonifácio", da 5a. Inspetoria Regional;

b) sôbro possível sonegação da Renda Indigona, rulativamente à produção e venda do erva-mate;

c ) sôbre o alegado afastamento do Trabalhador - GI $-40 \underline{2}$ 1, Joño Peralta, que se diz disponsado do serviço por aquele ex-Encar. regado, no mês de setembro, continuando, entretanto, a figurar om fo Tha de pagamento aos meses posteriorus, de outubro, novembro o dezem bro.

d) so acuele ex-Incerregado era Procuredor do scus cux 1 liares, funcionários do mesmo Pôsto e, se nessa quelidado, tería pago ao Trabalhedor Zecaries Marquos (índio) a importn̂ncia de Cr\$.... Cr\$30.000,00 (TRINTh MIL CRUZiTiNS), em vez de fezer quitação do to tal dos pegementos por ôlo rocobidos, refurentes a selorio-família dequele Trabalhador.

\SS. Lourival de Fote Cabral-Diretor Substituto.

Fig.5: Sobre relações violentas e precárias de trabalho nos PI's.

Fonte: Relatório Figueiredo, p. 626. 
A Fig. 6, toca no sensível tema da presença de missionários nas terras indígenas, com um reiterado elogio ao trabalho de "civilização" dos índios por eles realizado:

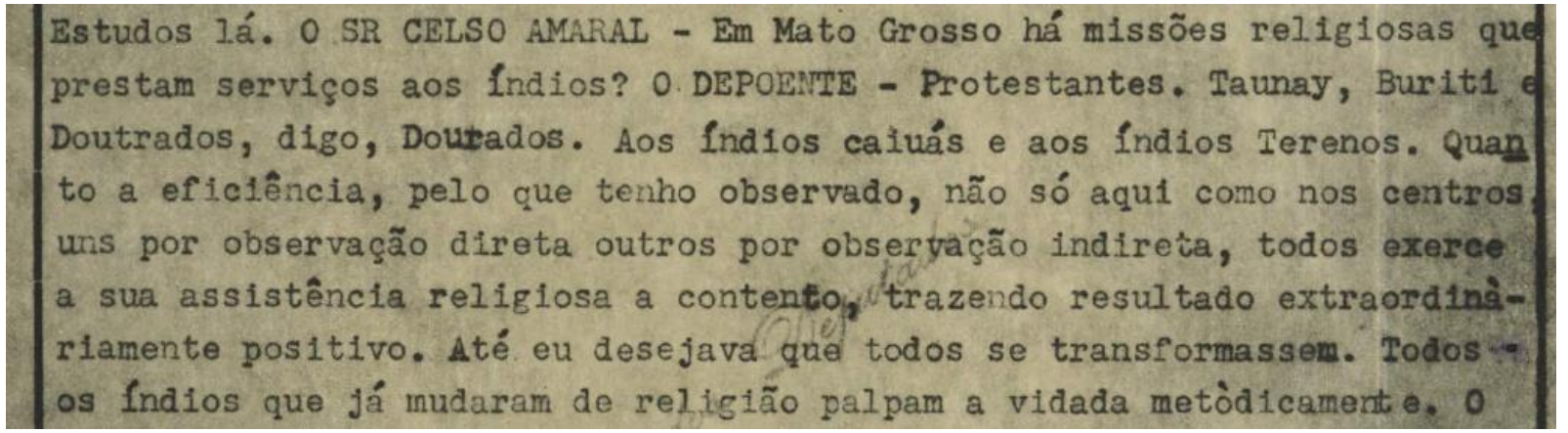

Fig.6: Sobre a avaliação positiva de funcionários quanto ao trabalho de aculturação de missões religiosas. Fonte: Relatório Figueiredo, p. 1143. 
A fig. 7 é um telegrama do ano de 1967 no qual um funcionário do SPI comunica mais um assassinato fortuito e sem causa conhecida de um indígena Kaiowá enquanto este pescava com a família:

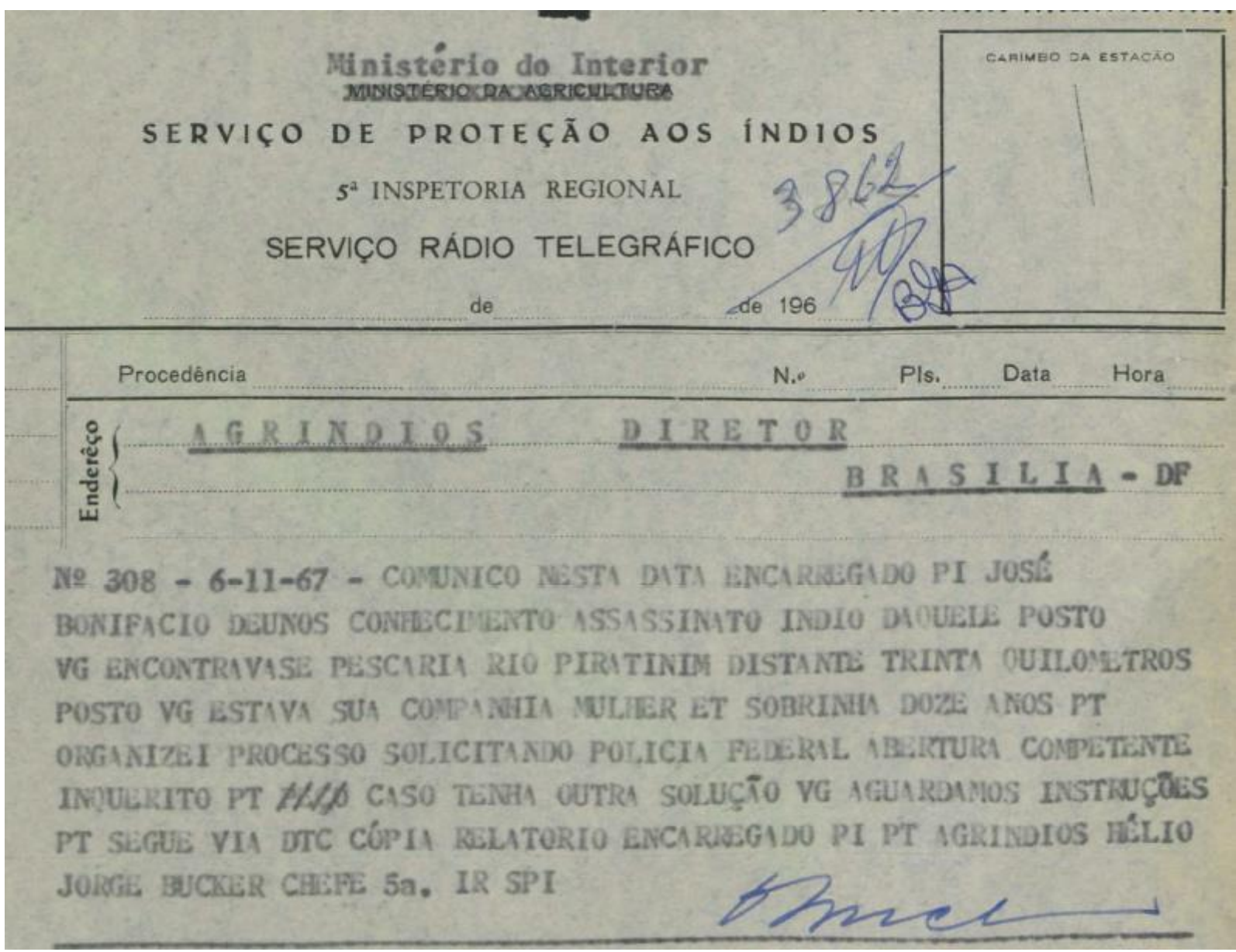

Figura 7: denúncia de assassinato de indígena.

Fonte: Relatório Figueiredo, p. 3862.

O alcoolismo, tema tão problemático na camada midiática e no cotidiano das cidades que estão no entorno das terras indígenas (CAVALCANTE, 2013), mostra sinais de suas raízes profundas. Na fig. 8, excerto de um documento interno do SPI, vê-se como as práticas de venda de álcool perto ou nos PI's era problemática, merecedoras de pedido de proibição por parte do órgão indigenista: 
Em tempo: Solicitamos a Chefia providencias no sentido de por fim à venda de pedidas alcoolicas aos indios, venda feita por muitos bulicheiros que limitam col - Pösto Indigena Benjamin Constant.

o Delegado da Cidade bem como o Comandante do $172 \mathrm{RC}$ mostraram-se interessados em acabar com a venda. Mas e necessario reiterar o pedido.

Figura 8: sobre a venda indiscriminada de bebidas alcoólicas. Fonte: Relatório Figueiredo, p. 1143.

A fig.9, depoimento de Helio Jorge Bucker, chefe da $5^{\text {a }}$ Inspetoria Regional do SPI, evidencia o esquema espoliativo que envolvia o Ministério da Agricultura, agentes do SPI e políticos do então estado de Mato Grosso:

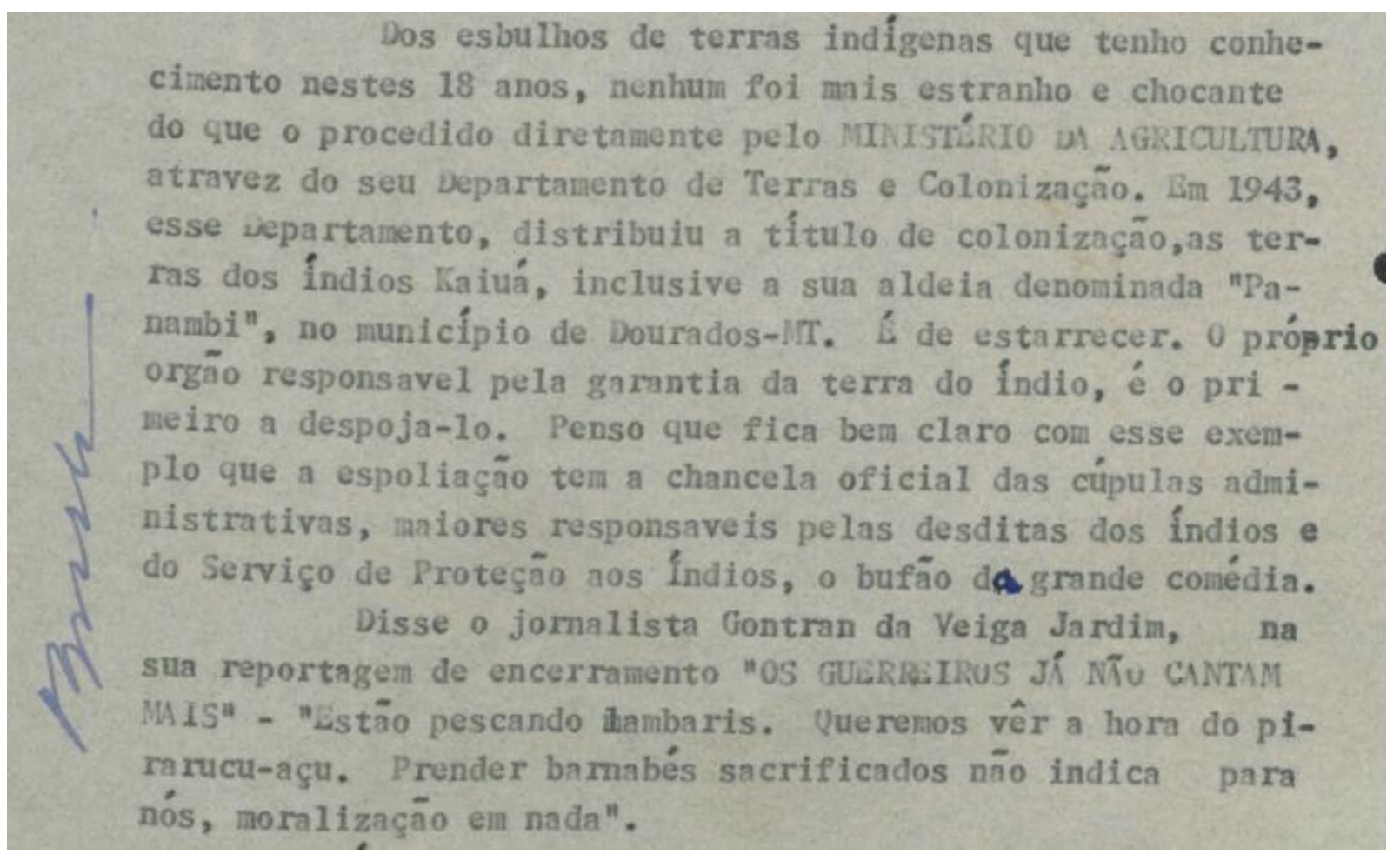

Fig. 9: Esbulhos de terra pelo Estado brasileiro.

Fonte: Relatório Figueiredo, p. 744.

Dentre os crimes, infratores e irregularidades de agentes privados contra indígenas, destacamos, pela crueza, o exemplo da Fig.10 que trata do crime de escravização: 


\section{ITANAT ZWTCHER STMÖ:S}

\section{Bscravizou por 2 anos o fndio Manuelzinho de tribo Guiranl ( 1 . 1682).}

Fig.10: Exemplo de crime de escravização cometido contra indígena.

Fonte: Relatório Figueiredo, p. 1088.

A partir dos exemplos acima, podemos depreender a importância da rediscussão da repressão no campo e nas florestas como uma face bem importante do projeto de país levado a cabo no período da última ditadura militar. Mas, além da pouca reverberação midiática do Relatório Figueiredo ${ }^{15}$, aparece um outro tipo de resposta, a campanha publicitária "Agro: indústria-riqueza do Brasil", como veremos na seção seguinte.

\section{Anos depois: "O Agro é pop, o agro é tech, o agro é tudo" a campanha publicitária do agronegócio da Rede Globo e os recordes ocultados do MS}

Em junho de 2016, a Rede Globo passou a veicular, em cadeia nacional, a campanha intitulada "Agro: indústria-riqueza do Brasil" cujo slogan é "Agro é tech, agro é pop, agro é tudo". Produzida pela gerência de marketing da rede de telecomunicações, a campanha tem previsão de veiculação até junho de 2018, sendo composta por 52 programas de um minuto que, segundo o gerente geral de marketing da emissora, têm como objetivo "tratar a importância dos produtos agrícolas e das coisas do campo para a sociedade brasileira. Os produtos agrícolas estão inseridos no dia-a-dia de todo cidadão urbano. Procuramos também sempre citar quantos empregos aquela atividade agrícola gera e quanto ela movimenta na economia" ${ }^{16}$.

Ainda segundo Roberto Schmidt, a campanha surge a partir da necessidade do agronegócio de "investir na construção de sua marca junto à população em geral, a fim de

\footnotetext{
${ }^{15} \mathrm{Um}$ levantamento preliminar e de caráter exploratório feito pela pesquisadora Elena Guimarães (2015) recuperou um conjunto de 20 matérias e artigos assinados publicados em veículos de imprensa impressos no ano de 2013 tematizando o Relatório Figueiredo e/ou sua redescoberta. O jornal Estado de Minas foi o veículo que mais falou sobre o assunto com 5 reportagens, seguido da Folha de São Paulo e Revista Carta Capital com 4 registros cada um. Dentre grandes veículos, o jornal Estado de São Paulo e a revista Isto É publicaram um artigo cada um. Eliane Brum (El País), Vladimir Safatle (Carta Capital), Demétrio Magnoli (Folha de São Paulo) e Egydio Shwade (Carta Capital) são alguns dos especialistas que assinam artigos especiais sobre o tema.

${ }^{16}$ Matéria publicada no G1, de 01/09/2016 com o título "Agronegócio é valorizado em campanha da Rede Globo" (http://g1.globo.com/economia/agronegocios/agro-a-industria-riqueza-dobrasil/noticia/2016/10/agronegocio-e-valorizado-em-campanha-da-rede-globo.html).
} 
criar empatia e confiança e mostrar que a riqueza gerada pelo agronegócio movimenta os outros setores da economia e fazer com que o brasileiro tenha orgulho do agro" ${ }^{17}$.

Dentre os vários programas da campanha, destacamos, para reflexão, o programa "Soja é agro" como "colecionadora de recordes" e coloca o Brasil no topo mundial da exportação de soja, atingindo em 2016, 26 bilhões de dólares em vendas.

Muito desses dados tem como um dos principais responsáveis o estado do Mato Grosso do Sul (MS). Em anos consecutivos, o MS superou o recorde da sua produção de safra. Segundo matéria "Produção de soja é recorde no Mato Grosso do Sul"19, divulgada no dia 22 de abril de 2017, no site de notícias Revista Globo Rural, as lavouras de soja renderam 8,49 milhões de toneladas, referentes a 56,2 sacas do grão para cada hectare plantado.

$\mathrm{Na}$ lista dos principais municípios produtores de soja do estado, estão o município de Maracaju, na liderança do ranking, com colheita de 903,118 mil toneladas e, em seguida, os municípios de Ponta Porã, com 669,401 mil toneladas, Sidrolândia, com 614,181 mil toneladas, Dourados 558,553 mil toneladas e Aral Moreira, com 406,468 mil toneladas ${ }^{20}$.

Existem outros dados e números que nos revelam a complexidade instaurada regionalmente. Essas informações, por vezes, escondidas - a exemplo do Relatório Figueiredo - ou divulgadas aleatoriamente pela mídia local, dificultam entendimentos sobre o enredamento do estado do MS, sobretudo quando envolve questões sobre os conflitos de terra. Se por um lado, o vídeo "Soja é agro" enaltece os dados das produções de safras e a relação da matéria-prima com a vida das populações urbanas brasileiras, por outro lado, corrobora o dispositivo da colonialidade da memória ao esconder as violências existentes naquele estado que garantem tais "ganhos" de modernização.

Em 2011, o Conselho Indigenista Missionário (CIMI) divulgou relatório intitulado “As violências contra os povos indígenas em Mato Grosso do Sul e as resistências do Bem Viver por uma terra Sem Males/ 2003-2010" que trata, detalhadamente, sobre os conflitos de

${ }^{17}$ Matéria publicada no site UAGRO, de 31/03/2017 com o título "Agronegócio tem que mostrar à sociedade a tecnologia usada no campo" (http://www.uagro.com.br/editorias/tecnologia/2017/03/31/agronegocio-tem-quemostrar-a-sociedade-a-tecnologia-usada-no-campo.html).

18 "Soja é agro", disponível em (https://www.youtube.com/watch?v=8oNBa68khKk)

${ }^{19}$ Matéria publicada no site Revista Globo Rural, de 22 de abril de 2017, com o título "Produção de soja é recorde no Mato Grosso do Sul (http://revistagloborural.globo.com/Noticias/Agricultura/Soja/noticia/2017/04/producao-de-soja-e-recorde-emmato-grosso-do-sul.html)

${ }^{20}$ Matéria publicada no site G1, de 20 de abril de 2017, com o título "Produção supera expectativas e MS colhe supersafra com 8,497 milhões de toneladas de soja"(http://g1.globo.com/mato-grosso-do-sul/noticia/producaosupera-expectativas-e-ms-colhe-supersafra-com-8497-milhoes-de-toneladas-de-soja.ghtml). 
terra instaurados no MS. Ao passo das atrocidades cometidas durante a Ditadura Civil-Militar e aqui explicitadas através de trechos do Relatório Figueiredo, as violações de direitos contra às populações indígenas, especialmente os Guarani-Kaiowá, permanecem e revelam números alarmantes.

Durante o período de 2003 a 2010, segundo relatório do CIMI, cerca de 250 lideranças indígenas foram assassinadas no Mato Grosso do Sul. No mesmo período, foram registradas 202 assassinatos de lideranças indígenas no restante do país, apontando o MS como território onde registrou-se cerca de 55,5\% dos assassinatos em todo Brasil.

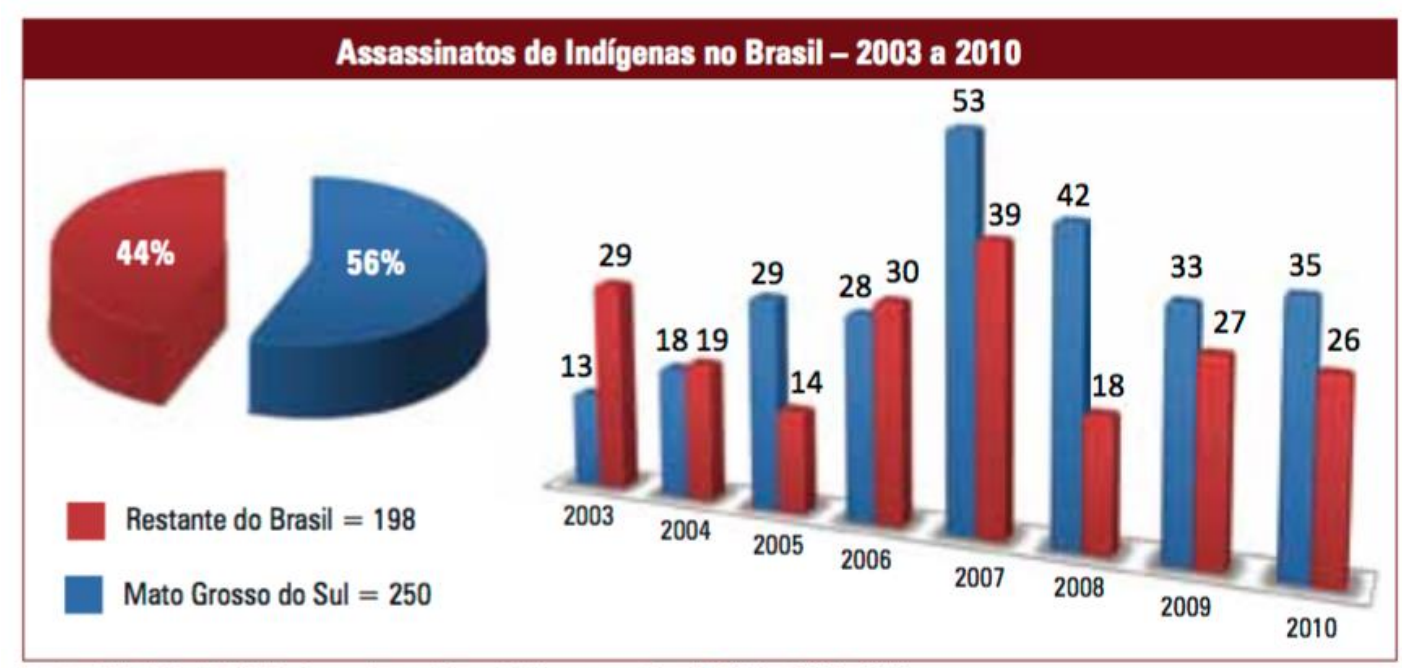

Fonte: Relatório de Violéncia contra os Povos indigenas no Brasil. CIMI - 2003- 2010

Se ampliarmos os dados para tentativas de assassinatos de indígenas no país, o MS mantém a liderança com 190 tentativas de assassinatos durante o período 2003/2010, em contraste com 111 tentativas de assassinatos em todo país.

Em 2010, dos 34 assassinatos ocorridos no MS, 16 aconteceram na Reserva Indígena de Dourados. Esse dado revela, como afirma em relatório, a procuradora Débora Duprat, uma das piores situações de conflitos do mundo, atingindo números de assassinatos superiores aos de países em estado de guerra declarada, como é o caso do Iraque.

Quadro comparativo: Iraque x Reserva Indígena de Dourados

\begin{tabular}{|c|c|}
\hline Iraque & Reserva Indígena de Dourados \\
\hline 93 assassinatos para cada 100 mil pessoas & 145 assassinatos para cada 100 mil pessoas \\
\hline
\end{tabular}


Outro dado explicitado no Relatório que compõe os números em relação a violência no MS, é o fato alarmante do número de suicídios cometidos, principalmente, por jovens. Os motivos são complexos e delicados e envolvem componentes culturais e sociais (OLIVEIRA, BENITES, OLIVEIRA NETO, 2016; FOTTI, 2004; PIMENTEL, 2006). Porém, a realidade de extrema violência e a situação de confinamento é apontada como a principal responsável pela situação dos suicídios. Entre 2003 a 2010, os números de suicídios de indígenas no MS atingiram $83 \%$ dos suicídios de indígenas no Brasil.

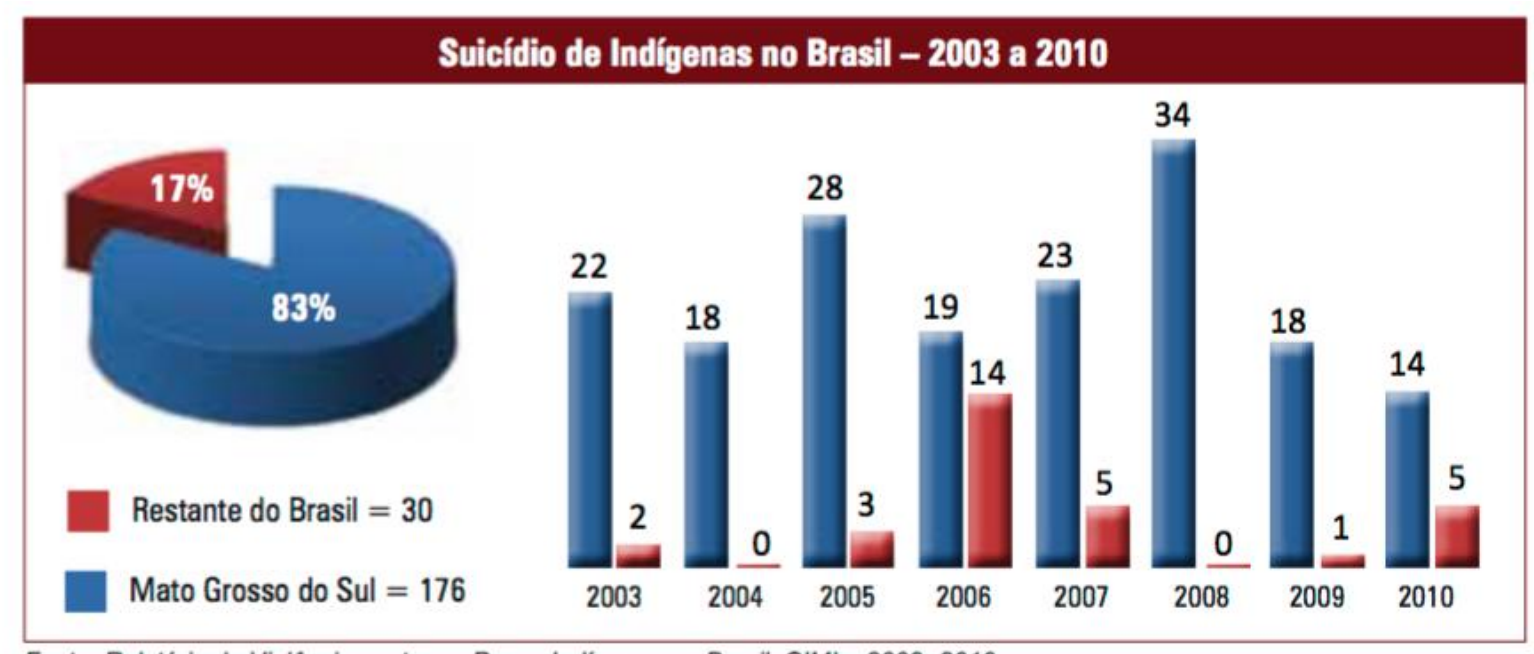

Fonte: Relatório de Violência contra os Povos Indigenas no Brasil. CIMI - 2003- 2010

Outro fator que permeia a situação de violência no MS está relacionado aos números de mortes causados por atropelamentos. A vulnerabilidade nas encostas das rodovias, os suicídios e os assassinatos de lideranças Guarani Kaiowá, arrasta uma realidade secular de violações dos direitos originários.

\section{Considerações finais}

Buscamos no presente artigo obviar o dispositivo de colonialidade da memória ao cotejar dados do Relatório Figueiredo com a campanha publicitária Agro: Indústria-Riqueza do Brasil e com dados contemporâneos sobre violências contra indígenas Guarani e Kaiowá no estado brasileiro de Mato Grosso do Sul. Por meio dessa aproximação que não se quer comparação - esse procedimento seria impossível já que se tratam de produções, linguagens e materialidades diferentes em sua realização e circulação - vemos se concretizar a modernidade/colonialidade que tentamos caracterizar conceitual e historicamente na primeira seção do artigo: a modernização do rural agrário esconde sua face violenta e genocida. Essas 
são as circunstâncias nas quais os recordes produtivos do Estado transformam-se em capital político para aqueles que os detêm ou alferem ganhos deles, deixando à parte a situação histórica de assassinatos, confinamentos, abusos e exploração vividas pelos Guarani e Kaiowá. Tal tema mostrou-se de extremo interesse da opinião pública nacional e internacional quando, por exemplo, em 2012, o movimento indígena Aty Guasu Guarani e Kaiowá ${ }^{21}$ (Grande Assembléia dos Povos Guarani e Kaiowá) conseguiu furar as blindagens políticomidiáticas às pautas dos grandes veículos de imprensa e emplacou a visibilidade das reivindicações por direitos e a dureza da luta pela terra com a carta da comunidade do tekoha Pyellito Kue/Mbarakay (OLIVEIRA, BENITES, OLIVEIRA NETO, 2016). As violações cometidas no período da ditadura militar e aquelas cometidas nos últimos dez anos não são fatos separados ou episódicos e ecoam novos sentidos quando aproximadas da propaganda festiva do agronegócio. A força do testemunho do documento histórico e dos dados quantitativos faz ver que não se trata de um passado distante e de um Brasil "atrasado". Antes, são signos contemporâneos da violência contínua da herança colonial que se insinua como um custo da modernidade, um custo que promove o apagamento, a invisibilização e o extermínio de vidas e formas de vida em longa duração histórica. Do ponto de vista dos estudos comunicacionais e da formação profissional nessa área, seja em jornalismo, publicidade ou relações públicas, fica o grande desafio no campo da pesquisa, do ensino e da extensão: o de dar conta, efetivamente, do diálogo intercultural (WALSH, 2002) num horizonte de simetria com populações e coletivos de menor poder social e torna-los públicos e visíveis bem como incidentes nas formas de saber das universidades, das organizações, da imprensa e da opinião pública. Tal postura exige, como mencionamos, o alargamento do horizonte epistemológico e uma ruptura com visão de ciência com a qual temos historicamente trabalhado.

\footnotetext{
${ }^{21}$ Para uma história do movimento Aty Guasu ver Almeida (2001) e Benites $(2012 ; 2014)$.
} 


\section{Referências}

ALMEIDA, R. F. T. Do Desenvolvimento Comunitário à Mobilização Política: O Projeto Kaiowá-Ñandeva como Experiência Antropológica. Rio de Janeiro: Contra Capa Livraria, 2001.

ANSARA, S. Políticas de Memória X Políticas do Esquecimento: possibilidades de desconstrução da matriz colonial. Revista Psicologia Política, v. 12, n. 24. pp. 297-311, mai/ago, 2012.

BALLESTRIN, Luciana. América Latina e o giro decolonial. Rev. Bras. Ciênc. Polít., Brasília, n. 11, p. 89-117, Ago. 2013. Disponível em:

$<$ http://www.scielo.br/scielo.php?script=sci_arttext\&pid=S010333522013000200004\&lng=en $\& n r m=i s o>$. Acesso em: 1 jun. 2015.

BENITES, T. História da Aty Guasu. In: Blog da Aty Guasu, 2012. [post]. Disponível em: http://atyguasu.blogspot.com.br/ Acesso em 20/01/2016.

. Rojeroky hina ha roike jevy tekohape (Rezando e lutando): o movimento histórico dos Aty Guasu dos Ava Kaiowá e dos Ava Guarani pela recuperação de seus tekoha. Tese de Doutorado defendida junto ao Programa de Pós-graduação em Antropologia Social/PPGAS - Museu Nacional/URRJ, Rio de Janeiro, 2014.

BRAGA, C.F. e CAMPOS, P.H.F. Invisíveis e subalternos: as representações sociais do indígena. Psicologia \& Sociedade; 24(3): 499-506, 2012.

BUTLER, J. Quadros de Guerra: quando a vida é passível de luto? Rio de Janeiro, Civilização Brasileira, 2017 (2a ed).

CAVALCANTE, T. L. V. Colonialismo, Território e Territorialidade: a luta pela terra dos Guarani e Kaiowá em MS. Tese de Doutorado apresentada à Faculdade de Ciências e Letras de Assis - UNESP - Universidade Estadual Paulista, Assis, 2013.

CIMI. As violências contra os povos indígenas em Mato Grosso do Sul e as resistências do Bem Viver por uma Terra sem Males, 2011 [RELATÓRIO DE PESQUISA].

CUNHA, M.C. da Cultura com aspas e outros ensaios. São Paulo; Cosac Naify; 2009.

Índios no Brasil: História, Direitos e Cidadania. São Paulo, Claro Enigma, 2012.

DATAGRO. Agronegócio tem que mostrar à sociedade a tecnologia usada no campo. 31 de março de 2017. Universo Agro. Disponível

$<$ http://www.uagro.com.br/editorias/tecnologia/2017/03/31/agronegocio-tem-que-mostrar-asociedade-a-tecnologia-usada-no-campo.html $>$.

FOTI, Miguel. A morte por jejuvy entre os guarani do sudoeste brasileiro. Fundação Nacional de Saúde, Brasília, Jan. 2004 (policopiado). 
FREIRE, J. R. B. Cinco idéias equivocadas sobre o índio. In Revista do Centro de Estudos do Comportamento Humano (CENESCH). Manaus, n. 01, setembro/2000. Pp 17-33.

G1, Redação. Agronegócio é valorizado em campanha da Rede Globo. 1 de outubro de 2016. Disponível <http://g1.globo.com/economia/agronegocios/agro-a-industria-riqueza-dobrasil/noticia/2016/10/agronegocio-e-valorizado-em-campanha-da-rede-globo.html>

GLOBO RURAL, Redação. Produção de soja é recorde no Mato Grosso do Sul. 22 de abril de 2017. Disponível

$<$ http://revistagloborural.globo.com/Noticias/Agricultura/Soja/noticia/2017/04/producao-desoja-e-recorde-em-mato-grosso-do-sul.html>

GOMES, M. P. O que se pensa do índio. In: Os índios e o Brasil: passado, presente e futuro. Editora Contexto, São Paulo, 2012. P. 140-170.

GOMES, G. Entrevista concedida à Luciana de Oliveira. Materiais do Trabalho de Campo da Pesquisadora. 2016. [entrevista].

GONDAR, Jô. Quatro proposições sobre a memória social. In: GONDAR, Jô \& DODEBEI, Vera. (orgs.). O que é memória social? Rio de Janeiro: Contracapa, 2005.

GROSFOGUEL, Ramon. Para descolonizar os estudos de economia política e os estudos póscoloniais: transmodernidade, pensamento de fronteira e colonialidade global. Revista Crítica de Ciências Sociais, n. 80, Coimbra, 2008, pp. 115-147.

GUIMARÃES, E. Relatório Figueiredo: entre tempos, narrativas e memórias. Dissertação (Mestrado em Memória Social) - Programa de Pós-Graduação em Memória Social/Programa de Pós-Graduação em Memória Social - Universidade Federal do Estado do Rio de Janeiro, Rio de Janeiro, 2015.

MELATTI, J. C. O índio e o civilizado: o que pensa um do outro. In: Índios do Brasil. 2007. Edusp. São Paulo. P. 255-270.

MIGNOLO, W. Diferencia Colonial y Razón Post-Occidental. In: CASTRO-GOMEZ, E. (ed). La reestructuración de las ciencias sociales en América Latina. Bogotá, Instituto Pensar, 2000.

Trayectorias de re-existencia: ensayos en torno a la colonialidad/decolonialidad del saber, el sentir y el creer. Bogotá, Universidad Distrital Francisco José de Caldas, 2015.

Monteiro, J. M. Negros da terra: índios e bandeirantes nas origens de São Paulo. SãoPaulo,Companhia das Letras,1994.

OLIVEIRA, Luciana. Em nome da liberdade de expressão: visões críticas da visibilidade da causa Guarani e Kaiowa. In: LIMA, Venício; GUIMARÃES, Juarez Rocha (Org.). Mídia e Liberdade de Expressão. São Paulo: Paulus, 2013. 
OLIVEIRA, L.; BENITES, T.; OLIVEIRA NETO, R. Sacrifício e quase-acontecimento: apontamentos sobre a visibilidade da luta pela terra dos povos indígenas Guarani e Kaiowa. Cadernos de História, Belo Horizonte, v. 17, n. 26, $1^{\text {º }}$ sem. 2016.

OLIVEIRA, L. Etnografia, pesquisa multissituada e produção de conhecimento no campo da comunicação. QUESTÕES TRANSVERSAIS - REVISTA DE EPISTEMOLOGIAS DA COMUNICAÇÃO. , v.5, p.72 - 81, 2017.

PIMENTEL, S. Sansões e guaxos. Suicídio guarani e kaiowá. Uma proposta de síntese. Dissertação de Mestrado apresentada no Programa de Pós-Graduação em Antropologia Social da Faculdade de Filosofia, Letras e Ciências Humanas da Universidade de São Paulo, 2006.

. Cosmopolítica kaiowá e guarani: uma crítica ameríndia ao agronegócio.

Revista de Antropologia da UFSCar, v.4, n.2, jul.-dez., p.134-150, 2012.

QUIJANO, A. Colonialidad y Modernidad/Racionalidad. Revista Peru Indigena, 13(29): 1120, 1992. . Colonialidade do poder, eurocentrismo e América Latina. In: LANDER, Edgardo (Org.) A colonialidade do saber: eurocentrismo e ciências sociais. Perspectivas latino-americana, Buenos Aires: Clacso, 2005, p. 227-278.

ROLNIK, R. Guerra dos Lugares: A colonização da terra e da moradia na era das finanças. Rio de Janeiro: Boitempo editorial, 2015.

SOMMER, D. O Guarani e Iracema: um idigenismo de duas faces. In: Ficções de fundação: os romances nacionais da América Latina. 2004. Belo Horizonte. Editora UFMG. P. 165-201

TACCA, F. de. O índio na fotografia brasileira: incursões sobre a imagem e o meio. Revista História, Ciências, Saúde-Manguinhos [online]. vol.18, n.1, pp.191-223, 2011.

VIEGAS, Anderson. Produção supera expectativas e MS colhe supersafra com 8,497 milhões de toneladas de soja. 20 de abril de 2017. G1 Mato Grosso do Sul. Disponível <http://g1.globo.com/mato-grosso-do-sul/noticia/producao-supera-expectativas-e-ms-colhesupersafra-com-8497-milhoes-de-toneladas-de-soja.ghtml> .

WALSH, C. (De)Construir la interculturalidad. Consideraciones críticas desde la política, la colonialidad y los movimientos indígenas y negros en el Ecuador. In: FULLER, N. (ed.) Interculturalidad y Política, Lima: Red de Apoyo de las Ciencias Sociales, 2002. 